\title{
Spillovers of Technology Transfer from FDI: The Case of Estonia ${ }^{1}$
}

\author{
Evis Sinani \\ Center for East European Studies, Copenhagen Business School, \\ Howitzvej 60, 2000 Frederiksberg, Denmark \\ Email: es.cees@cbs.dk \\ and \\ Klaus E. Meyer \\ (Corresponding Author) \\ Center for East European Studies, Copenhagen Business School, \\ Howitzvej 60, 2000 Frederiksberg, Denmark \\ Email: km.cees@cbs.dk
}

Forthcoming,

Journal of Comparative Economics, 2004 


\title{
Spillovers of Technology Transfer from FDI: \\ The Case of Estonia
}

\begin{abstract}
Foreign Direct Investment (FDI) is expected to generate technology spillovers to indigenous firms in transition economies. This paper disentangles the positive effect of technology transfer on the productivity of domestic firms from that of competition. We use a production function framework to estimate the impact of technology transfer from FDI on the growth of sales of domestic firms in Estonia during the period from 1994 to 1999. Employing panel data techniques, we control for industry and firm specific effects and use a Heckman two-stage procedure to control for sample self-selection bias. We find that the magnitude of the spillover effect depends on the characteristics of incoming FDI and, of the recipient local firm. More specifically, spillovers vary with the measure of foreign presence used, and are is influenced by the recipient firm's size, its ownership structure and its trade orientation.
\end{abstract}

Keywords: Spillovers, Technology Transfer, Panel Data JEL classification numbers: C23, D24, L11, L60, P31 


\section{Introduction}

Foreign direct investment (FDI) contributes to economic growth in host economies directly and indirectly. FDI adds directly to employment, capital, exports, and new technology in the host country (Blomström, Zejan and Kokko, 2000). In addition, local firms may benefit from indirect effects of improved productivity through, demonstration effects and labor mobility. These externalities are commonly known as spillovers because foreign investors cannot appropriate them fully. The expectation of attaining FDI spillovers has motivated governments in many transition economies to adopt policies aimed at attracting investors. These countries need to modernize their industrial structure, upgrade their infrastructure, and acquire new capabilities. The restructuring of enterprises is a core policy objective of economic transition and a central issue in economic research on transition economies (Jones et al., 1998, Estrin, 2002, and Buck et al., 1998). IMF et al. (1991) and Meyer (2001) argue that FDI provides a vital source of investment funds for both the state sector and the growing private sector, contributes managerial skills, new technology and capital, and promotes competition.

These contributions benefit both the foreign-owned business and the domestic firms interacting with the foreign-owned entity. Domestic firms gain by both backward or forward linkages, demonstration effects, and the modern technology acquired from multinational corporations (MNCs). However, domestic firms may also suffer negative externalities, e.g. the loss of skilled employees to MNC affiliates. In the short run, increased competition from MNCs may reduce the local firm's market share, even as it induces some firms to upgrade their resource utilization and improve their competitiveness. According to UN (2001), the positive effects outweigh the negative 
ones in most cases. The results of studies investigating the effects of FDI on local industry are mixed for both developing countries, e.g. Haddad and Harrison (1993) and Aitken and Harrison (1999) and for transition economies, e.g. Djankov and Hoekman (2000) and Konings (2001). However, few authors explore the conditions under which positive spillovers occur. In this study, we provide new evidence on the size of technology spillovers on the productivity of local firms and on the industry conditions that favor spillovers.

We focus on technology transfer spillovers that affect the growth of sales of local firms in the same industry, and examine their magnitude and the manner in which they vary with the domestic firm's characteristics. In addition, our analysis incorporates industry competition. We analyze these issues using firm-level panel data for the Estonian manufacturing sector (Jones and Mygind, 1999). We find that the magnitude of the impact coefficients varies among three alternative proxies for spillovers; hence, different types of inward FDI generate different spillovers. Moreover, spillovers depend on the recipient firm's size, its ownership structure and its trade orientation. Domestic firms benefit from competition from both foreign and other domestic firms because such competition forces them to upgrade their productivity. Furthermore, although human capital increases the local firm's growth of sales, its potential migration to foreign firms reduces significantly this effect. Finally, we find that technology spillovers are significantly larger for outsider-owned firms, which contributes to the ongoing debate over the relative merits of different ownership forms in transition economies (Estrin and Wright, 1999). 
Section 2 outlines the theoretical foundations, discusses prior empirical research, and presents key methodological issues. Section 3 introduces the empirical methodology and describes the data. Section 4 presents the results of both aggregate analysis and those for a separation into sub-samples by firm size, trade-orientation, and ownership. Section 5 summarizes the results and offers policy implications.

\section{Spillovers from Foreign Direct Investment}

Multinational corporations (MNCs) produce, control, and own most of the world's technology; and they are responsible for almost 80 percent of all private R\&D expenditures worldwide (Dunning, 1992). By encouraging MNCs to invest, developing countries hope to generate technology spillovers because FDI transfer intangible assets to the affiliate, which may then diffuse to local firms (Blomström and Kokko, 1996). Technology is transferred across countries in several ways. International trade transfers technologies embodied in goods, e.g., new varieties of differentiated products or capital goods and equipment. Contractual agreements, such as licensing, may transfer technology by trade in intellectual property. FDI transfers knowledge within the boundaries of an MNC or between a foreign firm and a local joint-venture partner. Of these possibilities, FDI is often considered to be the most attractive because it permits transfers of technologies that are otherwise difficult to obtain.

From the MNC’s perspective, the preferred mode of technology transfer depends on the characteristics of the technology itself, e.g., its age and complexity, and the features of the host country, e.g., the level of education of the workforce, labor skills, technology transfer requirements, and competition. Mansfield and Romero (1980) find 
that technologies transferred to affiliates in developed countries are younger than those transferred to affiliates in developing countries, although the technology transferred by licensing or joint ventures is older than the technology transferred to affiliates. Hence, the more modern and complex the technology, the more MNCs prefer to transfer it to an affiliate rather than to a third party. Kogut and Zander (1993) show that attributes of technology, such as tacitness, codifiability, and teachability, determine the mode of transfer. Their results suggest that the more tacit or complex the technology, the more likely it is to be transferred to a wholly-owned subsidiary. On the other hand, codifiability and teachability improve the feasibility of licensing. Thus, if firms attempt to extract rents from their new and complex technologies, FDI is the preferred mode of transfer (also see Caves, 1999).

Although MNCs wish to retain technology internally, or to charge a market price for transfers to business partners, positive externalities in the form of technology spillovers may be created. The dissemination of technology leads to improvements in the productivity of local firms in ways that do not allow the MNC to capture all the related benefits. Such spillovers of technology transfer may arise in several ways. First, demonstration effects allow local firms to learn by observing MNCs operating higher level of technology. After noticing a product innovation or a new form of organization adapted to local conditions, local entrepreneurs may strive to imitate the innovation. As local businesses interact with existing technology users, information is diffused, uncertainty is reduced, and imitation levels increase (Blomström and Kokko, 1996). Second, local employees trained by MNCs may move to jobs in domestic firms, taking with them their upgraded human capital. Even rank-and-file staff acquires skills, attitudes 
and ideas on the job through exposure to modern organization forms and international quality standards. These people make a substantial contribution by raising productivity when working for local firms or when setting up new entrepreneurial businesses. ${ }^{2}$ Third, spillovers from backward and forward linkages occur through business transactions between foreign affiliates and both domestic suppliers and their customers. Foreign firms may purchase intermediate goods from domestic suppliers to economize on transportation costs or to accommodate local content requirements. Lall (1978) finds that MNCs improve the productivity of indigenous firms by providing technical assistance and training, by assisting them in purchasing of raw materials, and by pressuring suppliers to meet standards of reliability and speed of delivery.

Negative effects may arise from competition if foreign firms with advanced technologies produce at a lower marginal cost. By taking market share from domestic firms, MNCs may lower the productivity of domestic firms. Thus competition may have a negative impact on indigenous firms' productivity, especially in the short run (Aitken and Harrison, 1999). However, domestic firms may also react to foreign competition by using the existing technology more efficiently or by investing in new technology in order to maintain their market shares (Blomström and Kokko, 1996). Most prior studies measure only the net positive effect of technology transfer and the negative impact of competition, both due to foreign presence in the market. In this study, we disentangle the effect of technology transfer from that of competition by using control variables.

Empirical research analyzing FDI spillovers via technology transfer to domestic firms in transition, developing, and developed economies provides mixed results. Some studies find that foreign presence has a positive impact on the productivity of domestic 
firms, while others find no evidence or a negative effect. One source of these differences is that some studies use cross-section data while others use panel data. Cross-section specifications do not allow for the identification of the direction of causality between FDI and productivity improvements. A positive coefficient may be due to FDI spillovers contributing to local firms' productivity or it may be caused by MNCs investing in more productive sectors in the host economy. Therefore, Görg and Strobl (2001) and Aitken and Harrison (1999) argue that panel data analysis is a more appropriate method to determine productivity spillovers. By following a firm over time, panel data allow controls for firm-specific effects that are time invariant and possibly correlated with foreign presence in the sector. Failure to control for such effects may lead to biased results.

Studies that employ cross-section data at the industry or firm level often discover positive spillovers to domestic firms. Early studies that use industry level data, e.g., Caves (1974) for Australian manufacturing and Globerman (1979) for Canadian manufacturing, find positive and significant technology spillovers. Blomström and Persson (1983), Blomström and Wolf (1994), and Kokko (1994) find a positive effect of foreign presence on the growth of labor productivity or total factor productivity in local Mexican firms. Other studies use cross-section data at the firm level to examine the impact on productivity of individual plants. In a study of Taiwan, Chuang and Lin (1999) find positive and significant spillovers from both FDI and R\&D. In addition, labor quality, firm size, market structure and export orientation are shown to affect the productivity of firms. Kokko, Tasini and Zejan (1996) divide their sample into two subsamples by the size of the technology gap and find that spillovers are significant only in 
industries characterized by small technology gaps. In contrast, Sjöholm (1999) finds evidence of spillovers to domestic firms only in a sub-sample with a large technology gap in a study of FDI spillovers on productivity and productivity growth in Indonesia. Moreover, he finds that a large degree of competition increases spillovers. From this literature, the role of the technology gap in affecting FDI spillovers remains unresolved.

Most studies employing firm level panel data find no or negative evidence of spillovers to domestic firms. For Morocco, Haddad and Harrison (1993) examine the effect of foreign presence on the relative productivity of local firms by comparing firm level productivity with that of the best practice firm in the industry and find no evidence of spillovers. However, competition is shown to push local firms toward the best practice frontier in industries having a low level of technology. For Venezuela, Aitken and Harrison (1999) find negative spillovers, which they describe as a market stealing effect, because foreign investment reduces domestic plant productivity in the short run by forcing domestic firms to cut production. In addition, they test the possibility that spillovers are local and find no evidence to support this claim. For India, Kathuria (2001) finds that local firms do not benefit from a foreign presence, if this presence is measured as a share of sales, but they do benefit from having foreign capital stock available. Furthermore, when the sample is divided into scientific and non-scientific industries, spillovers from a foreign presence are found in scientific industries, but only if local firms invest in R\&D activities. Hence, R\&D and spillovers may be complementary. Feinberg and Majumdar (2001) estimate production functions for foreign and domestic firms in India and find that MNCs gain from each others' R\&D spillovers, although domestic firms do not. Investigating technology spillovers using panel data for 
manufacturing industries, Griffith (1999), Liu et al. (2000), Harris and Robinson (2003), and Haskel et al. (2001) find evidence that a foreign presence in the sector affects positively the productivity of domestic firms in the UK.

For European transition economies, Djankov and Hoekman (2000), Kinoshita (2001), Konings (2001), and Yudaeva et al. (2003) investigate technology transfer spillovers based on firm-level panel data. In addition, Liu (2002) investigates spillovers using industry data from China. Similar to studies on developing economies, these papers find no or negative spillovers to domestic firms. Konings (2001) finds negative spillovers to domestic firms in Bulgaria and Romania, which suggests that the crowding-out effect of competition dominates the positive effect of technology transfer. However, Konings finds no evidence of any spillovers to domestic firms in Poland. Djankov and Hoekman (2000) find a positive significant impact of FDI on the growth of sales for their entire sample of firm level data for the Czech Republic 1992 to 1996. However, contrary to what is predicted, spillovers have a negative impact on the growth of sales of domestic firms. Hence, growth of sales in the industry occurs in the foreign-owned firms while the technological level of local firms may be too low to enable them to absorb new knowledge that they encounter. Liu (2002) investigates the correlation between FDI presence and productivity growth in China using industry-level data, and finds a positive and significant effect of spillovers for the overall sample and for the sub-sample of domestic firms. Furthermore, the productivity of both state-owned and joint venture firms is more sensitive to the presence of FDI. However, these results may not be robust to using more disaggregated, firm-level panel data. 
The different results in the literature concerning the existence and the direction of spillovers from FDI are due to using aggregate versus firm-level data, to cross-section versus panel data analysis, and to different measures of spillovers at the industry level (Görg and Strobl, 2001). In this research, the coefficient on the foreign share is interpreted as a measure of spillovers. Controlling for differences of productivity across sectors, which may be correlated with foreign presence, is impossible with cross-section data. In other words, the observed correlation between foreign presence and the productivity of domestic firms may be due to foreign firms investing in industries that are more productive. Such an endogeneity problem leads to an upward bias of the spillover coefficient. In this paper, we employ a panel of firm-level data, which allows us to control for endogeneity and selection biases.

In this study we focus on how spillovers vary according to the characteristics of recipient firms, in addition to estimating the increase or decrease the productivity of domestic firms in the same industry. Domestic firms vary in their reaction to foreign entry with its resulting changes in competition, and to the higher technology level employed in foreign invested firms. Their reaction depends on the characteristics of the local firm, notably its ability to absorb technology. Cohen and Levinthal (1989), Glass and Saggi (2002), Keller (1996), and Borensztein et al., (1998) argue that absorptive capacity is a function of technology accumulation and human capital in that investment in new technology and skilled labor contributes to increased absorptive capacity. Moreover, Cohen and Levinthal (1989) point out that R\&D plays two roles; it not only simulates innovation but also increases a firm's absorptive capacity, i.e. its ability to identify, assimilate and exploit outside knowledge. ${ }^{3}$ 
Based on this literature, we include investment in intangible assets, investment in new machinery and equipment, and investment in human capital as measures of innovation at firm level. These investments cause direct and indirect effects on productivity. The direct effect consists of increased productivity due to superior technology and human capital. The indirect effect results from increased absorptive capacity, which in turn increases the ability of the firm to internalize and utilize outside technology and knowledge. We expect to find positive coefficients for the interaction terms of spillovers with intangible assets and with investment in new machinery and equipment. A negative coefficient on one of these terms would indicate that the local firm is unable to appropriate the benefits of its investments, possibly due to a large technology gap between foreign and domestic firms.

Moreover, we test if firms' own human capital helps them to attract productivity spillovers. ${ }^{4}$ On the one hand, if it increases their ability to benefit from positive spillovers, we would observe a positive coefficient for interaction term between human capital and foreign presence. On the other hand, MNCs pay higher wages to keep their trained workers from moving to domestic firms, as Aitken, Harrison and Lipsey (1995), Glass and Saggi (2002), and Fossuri, Motta and Rønde (2001) argue. These higher wages may even stimulate the movement of skilled labor from domestic to foreign firms. Such migration would have a negative impact on domestic firms with employees that are potentially attractive to foreign investors and could lead to a negative coefficient for the interaction term.

In conclusion, spillovers have a positive or negative impact on the productivity of local firms depending on whether the negative competition effect outweighs the positive 
effect of demonstration/imitation, training of employees and/or the positive effect of backward and forward linkages. The empirical literature finds mixed results concerning their existence and their sign. We aim to bring this stream of research forward by employing state-of-the-art panel data analysis, and employ different measures of spillovers at the industry level. We focus on identifying characteristics of local firms that explain the ability to benefit from foreign firm entry and the consequent change in competition.

\section{Methods of Empirical Analysis and the Data}

If the technology embodied in foreign-owned firms is transmitted to local firms, both productivity levels and growth rates of local firms should increase. Since productivity is analyzed with production functions, we begin by specifying a general form for the production function. To produce output $\mathrm{Y}$, the firm uses capital $\mathrm{K}$, labor $\mathrm{L}$ and materials M. For each firm, the production function is given by:

$Y_{i j t}=A_{i j t} F\left(K_{i j t}, L_{i j t}, M_{i j t}\right)$,

where $\mathrm{i}$ denotes the domestic firm, $\mathrm{j}$ the industry and $\mathrm{t}$ the year. We assume that the production function is homogenous of degree $g$ in inputs and that it both is increasing and concave in all its arguments. The term $\mathrm{A}_{\mathrm{ijt}}$ measures total factor productivity (TFP) or the Solow residual, which is assumed to vary across both firms and sectors and over time. In a survey of the literature on TFP, Felipe (1999) claims that $A_{i j t}$ captures elements such as managerial capabilities and organizational competence, R\&D, the inter-sector transfer of resources, increasing returns to scale, embodied technical progress, and the diffusion of technology. Hence, $A_{i j t}$ can be considered to be a function of such variables, following 
Haddad and Harrison (1993), Sjöholm (1999), Zukowska-Gagelman (2000) and Kinoshita (2001).

Taking the log of (1) and the time derivative, assuming perfect competition and expressing the growth of variables in discrete time, we transform equation (1) to the following:

$$
\begin{aligned}
& d Y_{i j t} / Y_{i j t}=d A_{i j t} / A_{i j t}+\left[d\left(\log Y_{i j t}\right) / d \log \left(K_{i j t}\right)\right]^{*} d K_{i j t} / K_{i j t}+\left[d \log \left(Y_{i j t}\right) / d \log \left(L_{i j t}\right)\right] * d L_{i j t} / L_{i j t} \\
& +\left[d \log \left(Y_{i j t}\right) / d \log \left(M_{i j t}\right)\right]^{*} d M_{i j t} / M_{i j t},
\end{aligned}
$$

where $d Y_{i j t}, d A_{i j t}, d K_{i j t}, d L_{i j t}$, and $d M_{i j t}$ are the time derivatives of logs. In addition, $d \log \left(Y_{i j t}\right) / d \log \left(Z_{i j t}\right)$ equals $b_{y z}$ where $Z_{i j t}$ represents $\mathrm{K}_{\mathrm{ijt}}, \mathrm{L}_{\mathrm{ijt}}$, or $\mathrm{M}_{\mathrm{ijt}}$, so that $b_{y z}$ is the elasticity of output with respect to the designated input. Hence, we rewrite (2) as:

$$
d Y_{i j t} / Y_{i j t}=d A_{i j t} / A_{i j t}+b_{y k} * d K_{i j t} / K_{i j t}+b_{y l} * d L_{i j t} / L_{i j t}+b_{y m} * d M_{i j t} / M_{i j t} .
$$

In discrete time, equation (3) becomes:

$$
\log \left(Y_{i j t+1} / Y_{i j t}\right)=d A_{i j t} / A_{i j t}+b_{y k} * \log \left(K_{i j t+1} / K_{i j t}\right)+b_{y l} * \log \left(L_{i j t+1} / L_{i j t}\right)+b_{y m} * \log \left(M_{i j t+1} / M_{i j t}\right)
$$

In the empirical analysis we express the growth of TFP as a function of variables suggested by the earlier theoretical discussion such as a firm’s investment in intangible assets, in new machinery and equipment, human capital, firm's export intensity and industry concentration. Moreover, we include industry and time dummies to account for the effect of the omitted variables. Appendix Table A1 describes the variables and their 
measurements. Following the empirical literature three alternative proxies are used to measure spillovers, namely, the share of the foreign firm's employment in total industry employment and the foreign share of both industry equity and industry sales. These spillover variables are defined as follows:

spillover $_{j, t}=\sum_{j} \mathrm{E}_{\mathrm{f}, \mathrm{t}-1} /\left(\sum_{j} \mathrm{E}_{\mathrm{d}, \mathrm{t}-1}+\sum_{j} \mathrm{E}_{\mathrm{f}, \mathrm{t}-1}\right)$,

where E stands for employment, equity or sales of the firm, respectively. Industry concentration is measured by two Herfindahl indices to represent foreign and domestic competition: high values indicate high degrees of industry concentration and less competition.

We expect coefficients for inputs to be positive and significant: however, the coefficient for a spillover variable may be positive or negative. A negative coefficient indicates either that foreign firms operate in isolation and impede spillovers or that domestic firms are not able to benefit from the foreign presence. The coefficients for investment in intangible assets, in new machinery and equipment, human capital, and exports are expected to be positive. Finally, the coefficients for industry concentration may be positive or negative because competition either makes domestic firms use existing technology more efficiently or leads to lower economies of scale.

Using the growth of sales of domestic firms as the dependent variable we employ both Fixed Effects (FE) and Generalized Least Squares (GLS) for panel data to estimate equation (4). ${ }^{5}$ As independent variables the specification includes growth in inputs, the spillover variable, the ratio of investment in intangible assets to output, the ratio of investment in new machinery and equipment to output, human capital, the interaction of 
these terms with the spillover variable, two Herfindahl indices, the ratio of export to output, and industry and time dummies.

We employ different panel data procedures to avoid estimation problems, namely, selection bias, endogeneity, autocorrelation and heteroskedasticity. Selection bias occurs when the dependent variable is not observed for all firms over the entire period due to bankruptcy, merger, or firms simply choosing not to report. Since selection bias leads to biased estimates (Greene, 2003), we apply a Heckman two-step procedure to calculate the probability that the firm is included in the sample based on firm's profit, its labor productivity and its industry affiliation. Then, the resulting inverse Mills ratio is included as an explanatory variable. Endogeneity can arise in two ways. First, foreign firms may invest in more productive industries leading to reverse causality. Second, the decision of domestic firms to invest in new machinery and equipment depends on past and current levels of output and profit, which in turn are affected by investment rates. To account for both sources of endogeneity, we use lagged values of the relevant variables as instruments.

Autocorrelation may result from the omission of unobserved variables, such as better management or organizational structure, that lead to the growth of firm sales to be correlated with the spillover variable. Heteroskedasticity arises from different firm and industry characteristics (Greene, 2003).

The data set contains yearly information on Estonian firms from 1994 to 1999, obtained from the Estonian Statistical Agency (ESA). Ownership information comes from a survey of firms that have been fully or partially privatized (Jones and Mygind, 1999). The sample also includes wholly state-owned firms in any given year. Financial 
and wage data are taken from the financial statements, i.e., balance sheets and income statements, from firms in a stratified random sample chosen to represent eighteen economic branches at three-digit isic/Nace classification. Within each industry, firms are divided into three employment groups, namely less than 20 employees, between 20 and 100 employees, and more than 100 employees. The data set includes firms with more than 10 employees in a given year.

The sample consists of 2,250 observations of which there are 405 firms in 1994, 434 in 1995, 420 in 1996, 377 in 1997, 320 in 1998 and 294 firms in 1999. The different number of firms over time is due to entry and exit of firms in the sample, with more firms entering than exiting in the first year, and more firms exiting than entering in later years. The sample is representative in that it covers $30 \%$ of the manufacturing employment in 1994. Appendix Table A2 presents the means and standard deviations for the principal variables. After first differencing the data to obtain the growth in sales and input variables, 1,339 observations remain for domestic firms and 359 for foreign firms.

In any given year, the data are expressed in current prices, so that controlling for inflation is important. Taking 1994 as the base year, all variables are deflated using the appropriate two digit PPI deflators. Three domestic ownership groups are distinguished, namely, insider-owned, state-owned, and outsider-owned firms. Foreign firms are those having at least $10 \%$ of their nominal capital owned by foreigners. ${ }^{6}$ We do not distinguish between joint ventures and FDI because the purpose of this study is to assess the impact of foreign firms on domestic firm performance through technology transfer.

Table 1 presents the number of observations by industrial affiliation for the total sample. The three measures of foreign presence are highest in the following industries: 
leather products, pulp and paper products, other non-metallic mineral products and electricity, gas and water supply. For the later industry, foreign share is highest only when measured as the share in employment and sales. In most industries, foreign presence is higher in industry sales than in industry employment and equity. The concentration of foreign presence in these industries may be due to either high productivity of these industries or because a high import content of the foreign-owned operations. The data shows that except for wood products, electrical and optical equipment and transport equipment, industry productivity is higher in industries with higher foreign share. We control for such industry-specific effect by industry dummies in the analysis.

To sum up, we estimate a production function framework augmented with firm and industry characteristics to test for the impact of variables expected to influence spillovers. We use GLS for panel data to control for both industry and firm specific effects and for selection biases.

\section{The Results}

In this section, we introduce the results of the empirical analysis. We start by presenting the results for the overall sample of firms and proceed showing the results for a separation into sub-samples by firm size, trade-orientation and ownership. Table 2 presents the estimation results for the three measures of spillovers using GLS for panel

data method, which is the most rigorous procedure methodologically. ${ }^{7}$ The dependent variable is firm-level sales growth of domestic firms. Spillovers are measured by three alternative proxies, namely the share of foreign firms' in industry employment, sales and 
equity respectively. In addition to the variables tabulated, the regression analysis moreover included several measures of inputs, i.e. capital, labor and materials. Thus, the dependent variable sales growth is relative to inputs, and thus indicative of improved total factor productivity.

In Table 2, many coefficients are significant at the $1 \%$ level. The effect of spillovers is positive and significant for all measures. Hence, domestic firms benefit from direct contact with foreign firms, independent of any effect due to investment and human capital. These estimates suggest that an increase of foreign presence by 10 percentage points would increase the sales' growth of domestic firms by $6.9 \%$ if the spillover variable is measured as the share in employment, by 3.9\% if it is measured as the share in sales, and by $1.7 \%$ if it is measured as the share in equity. Hence, spillovers have the largest effect when measured as the share in employment.

The effect of competition is captured by separate Herfindahl indices for foreign and domestic firms. These coefficients, except for the coefficient of the Herfindahl index for domestic firms in column 3, are negative and significant at the $1 \%$ level, suggesting that high concentration or a high market share of either foreign or domestic firms reduces the growth of sales of domestic firms. Our results are consistent with those of Wang and Blomstrom (1992) and Glass and Saggi (2002), who argue that the entrance of foreign firms increases competition with host country and forces inefficient indigenous firms to use existing technology more efficiently or to look for new technology for survival. After the least efficient firms are driven from the market, the remaining domestic firms compete with more efficient foreign firms by upgrading their operations, which increases their productivity. Furthermore, the coefficient on exports is positive and significant in all 
of our regressions indicating that firms with access to international markets and facing international competition experience higher sales growth. ${ }^{8}$

As predicted, the coefficients of intangible assets, investment in new machinery and human capital are all positive, and with the exception of intangible assets in columns 1 and 2 they are significant at the $1 \%$ or $5 \%$ level. Hence, a firm's own investment in tangible or intangible resources increases sales growth. By upgrading intangible assets or investing in new machinery and equipment, domestic firms also increase their absorptive capacity. The extent to which a firm is able to exploit external knowledge depends on its level of absorptive capacity as well as on the complexity of the external knowledge. Hence, if the technology gap between foreign and domestic firms is too large, because the technology of foreign firms is too advanced, local firms may not be able to comprehend and adapt foreign technology. Most of the interactive effects are negative and significant, with the exception of the interaction with intangible assets in column 2 and the interaction with human capital in column 3. These results indicate that domestic firms lack absorptive capacity due to a large technology gap. ${ }^{9}$ Regarding human capital, Aitken, Harrison and Lipsey (1995), Glass and Saggi (2002) and Fossuri, Motta and Rønde (2001), claim that foreign firms attract and retain highly qualified personnel by paying higher wages. In our data set, foreign firms pay an average real wage per worker that is higher than that of domestic firms by $65 \%$. Hence, the negative interactive term for human capital may depend on the real wage effect.

Pooling firms may hide important variations in spillover effects for different groups of firms. We thus conducted our analysis for subsamples by firm size, export orientation (Table 3) and ownership (Table 4). Large enterprises exploit economies of 
scale to take advantage of innovations, as, e.g., Schumpeter (1950) argues. Hence, if larger firms have more resources to exploit innovative opportunities, they should benefit more from foreign technology. On the other hand, small and medium-size enterprises are important sources of innovation and economic growth; Acs and Audretsch (1990) argue that smaller firms make important contributions to innovation by being less bureaucratic and by exploiting innovations that are too modest to interest large firms. Empirical evidence indicates that small firms generate more innovations than large firms (Acs et al. 1994 and 1999). Therefore, we investigate the effect of firm size on the spillover effect in Estonia.

Columns 1 to 3 of Table 3 show that the spillover effect using employment is largest in magnitude for small firms, yet small and insignificant for large firms. ${ }^{10}$ Although Aitken and Harrison (1999) find that firm size does not influence spillovers, Acs, Audretsch and Feldman (1994) find that small firms are able to exploit knowledge created by both university and private corporations, which may explain our result. The direct effect of investment in new machinery on sales growth is positive and significant. Although the effect of human capital is negative and significant for medium and large firms, it is positive and significant for small firms. The negative coefficient for medium and large firms may be due to the fact that human capital is proxied by average wages, which may measure the ability of employees to extract rents by diverting resources from productive use to individual compensation (Christofides and Oswald, 1992; Prasnikar and Svejnar, 1998). Therefore, employees in medium and large firms may be able to extract rents whereas those in small firms cannot. 
The coefficient of the interactive term of human capital with the spillover variable is positive and significant for large firms. A possible explanation for this coefficient is that competition from foreign firms may reduce the ability of employees to extract rents from domestic firms. In addition, large firms may be better able to retain qualified staff who might be tempted to work for a foreign firm. In contrast, the human capital interactive coefficient is negative and significant for small firms suggesting that they may suffer from migration of skilled employees to MNC affiliates. Furthermore, the lack of absorptive capacity is corroborated by the negative coefficients of intangible assets and investment in new machinery interactive terms. The coefficients of the Herfindahl indices for both foreign and domestic firms are negative and significant for small and large firms; however, only the domestic coefficient is negative for middle-size firms. ${ }^{11}$

Regarding trade orientation, export-oriented domestic firms produce for foreign markets so that they have additional channels through which they learn about advanced technology and management practices. To account for both factors, we divide the sample into firms that export and firms that produce only for the domestic market. The separate regressions are presented in columns 4 and 5 of Table 3 and the signs and sizes of the coefficients are remarkably similar. The spillover variable is slightly higher for nonexporting firms, which is plausible given that exporting firms interact with foreign firms abroad as well. Although the direct effect of investments in intangible assets, new machinery and equipment and human capital are positive and mostly significant, the interactive terms are negative and mostly significant, as we found for the entire sample. In contrast to exporting firms, which can benefit more from international competitors, 
non-exporting firms seem to benefit more from foreign firms located in the domestic market.

Finally, we investigate spillovers for domestic firms having different forms of ownership. As in other transition economies, the privatization process in Estonia resulted in full or partial transfer of ownership rights to different groups such as managers, employees, domestic institutions or individuals, and foreign firms or individuals (Djankov and Murrell 2002, Estrin 2002). We classify the resulting variety of ownership structures into three main groups, namely, insider-owned, domestic outsider-owned, and state-owned firms. Following Jones and Mygind (1999), we determine the group to which a firm belongs by the largest shareholding group in any given year. Ownership structure influences the firms' absorptive capacity and hence, its benefits from spillovers. Insiderowned firms tend to be small and labor-intensive with limited access to capital (Blanchard and Aghion, 1996). Therefore, we expect them to be less able to absorb technology and to cope with competition than domestic outsider and state-owned firms. Furthermore, the literature has shown that privatization is successful in improving performance only if the firm is controlled by outsiders (Djankov and Murrell, 2002; Frydman, Gray, Hessel and Rapaczynski, 1999). Therefore, we expect outsider-owned firms to respond to the presence of foreign firms better than either insider-owned or stateowned firms.

Two studies explore the link between ownership structure, spillovers and absorptive capacity. Buckley et al. (2002) find that foreign presence does not affect positively the productivity of state-owned firms, in contrast to its positive effect on collectively owned firms (COEs) in China. The authors infer that SOEs exhibit a lower 
level of competitiveness, absorptive capability, and motivation to learn relative to COEs. Zukowska-Gagelman (2001) finds that foreign presence has a significant negative impact on both state-owned and private firms in Poland in industries with high competition. In contrast, state-owned firms benefit from spillovers if competition is low. To analyze the impacts of different ownership forms we report regressions for each sub-sample in Table 4. The spillover variable is positive and significant for all ownership groups; however, the magnitude of the coefficient is significantly larger for outsider-owned firms. ${ }^{12}$ To the extent that the spillover coefficient for the outsider owned firms is significantly larger than those for state-owned and insider-owned firms, our results confirm those in Buckley et al. (2002).

Our results are consistent with the conclusion that privatization to outside owners is beneficial for firm restructuring and corporate performance. Outsider-owned firms may benefit more from spillovers because they are restructuring proactively and seeking new ideas about business management from foreign competitors. Absorptive capacity depends not only on human capital but also on organizational structures and cultures (Lane and Lubatkin, 1998). This effect may also be related to the fact that outsider-owned firms are more export-oriented, than the other ownership types, and thus access knowledge from in international markets through these channels. Although the direct impact of investment in intangible assets on the growth of sales is not positive, the indirect effect benefits the firm through increased absorptive capacity. In conclusion, ownership structure matters to a domestic firm's ability to benefit from spillovers of technology transfer.

\section{Conclusions}


We investigate the existence of spillovers from technology transfer to domestic firms in a transition economy and also the relationship between these spillovers and a domestic firm's absorptive capacity. In addition, we examine the influence of firm size, domestic firm trade orientation and ownership structure on the local firm's ability to benefit from spillovers. To analyze these issues, we disentangle the effects of technology transfer from those of competition by introducing control variables for technology and competition. We find that spillovers are of considerable magnitude in Estonia and that they depend on characteristics of the incoming FDI because labor and sales intensive-FDI generate larger spillovers than equity-intensive FDI. In contrast, prior studies using panel data techniques often fail to find positive effects of foreign presence on local productivity and growth. We also show that spillovers from technology transfer depend on the recipient firm's size, its trade orientation and its ownership structure. Small firms, nonexporting firms, and outsider-owned firms benefit more from spillovers than do other types of domestic firms.

Contrary to our expectations, own resources of domestic firms do not enhance their ability to attract spillovers; the pertinent interactive terms are mostly negative across firm types and for the overall sample of domestic firms. Given that domestic firms fail to catch up with foreign firms in most industries, we infer that the absorptive capacity of domestic firms is below the minimum threshold necessary to modify and apply the advanced technology of foreign firms. In fact, the absorptive capacity of domestic firms may decline further if skilled workers move to foreign firms. Finally, we demonstrate that competition from both foreign and domestic firms promotes sales growth for domestic 
firms. Perhaps, competition induces domestic firms to use their resources and existing technologies more efficiently, or to search for new and better ones.

The policy implications of these results for governments in host countries are complex. Conventional wisdom holds that governments welcome FDI because they expect potential positive spillovers from MNCs to the productivity of domestic firms. Although Estonian firms benefit from foreign presence in the market, the benefits do not increase with their own resource development. Because the technology gap may inhibit the utilization of foreign technologies by domestic firms, the government may provide support to domestic firms to help them learn from foreigners. For example, policies aimed at increasing local learning capabilities and labor skills may be essential to increasing the absorptive capacity of domestic firms. In addition, governments may increase spillovers from FDI by promoting competition. Wang and Blomström (1992) argue that competition reduces the technology gap between domestic and foreign firms, which forces foreign firms to transfer more technology to the host country. Our analysis confirms that competition increases the growth of sales of domestic firms. Hence, promotion of local competition would increase competitiveness and, consequently, the transfer of technology.

Further studies are needed to verify the robustness of our results by using alternative definitions of competition, such as import penetration in an industry. Moreover, the concept of absorptive capacity merits further research to understand better the determinants of the firm's ability to benefit more from foreign presence through its own efforts. We do not demonstrate that spillovers are associated with human capital or investment in tangible and intangible assets. However, the management literature uses a 
broader concept of absorptive capacity, which incorporates aspects of organizational structure and culture (Lane and Lubatkin, 1998; Lyles and Salk, 1996). Therefore, if better proxies are found, the expected interactions between spillovers and these variables may be confirmed. Future research should also attempt to distinguish the impact of FDI using more direct measurements. If data become available, separate intra- and interindustry spillovers should be considered. Alternatively, survey data may be collected to measure the different forms of interaction between domestic and foreign firms, following the approach by Chung et al. (2003), focusing on a single industry for which information on customer relationships is available. 
Appendix

Table A1: Variable Definitions

\begin{tabular}{|c|c|}
\hline Variables & Definitions \\
\hline $\begin{array}{l}\text { Dependent variable } \\
\left(\mathrm{Y}_{\mathrm{ijt}}\right)\end{array}$ & $\begin{array}{l}\text { The growth of sales by domestic firms constructed at the firm } \\
\text { level. Net sales are expressed in thousands of kroons. }\end{array}$ \\
\hline Employment $\left(\mathrm{L}_{\mathrm{ijt}}\right)$ & The average number of employees per year in a firm. \\
\hline Materials $\left(\mathrm{M}_{\mathrm{ijt}}\right)$ & $\begin{array}{l}\text { The sum of raw materials, fuel and electricity, in thousands of } \\
\text { kroons, at the firm level. }\end{array}$ \\
\hline Capital $\left(\mathrm{K}_{\mathrm{ijt}}\right)$ & $\begin{array}{l}\text { The average of fixed assets, between the beginning and end of } \\
\text { year for a firm, in thousands of kroons. }\end{array}$ \\
\hline Spillover & Spillovers measured by the share of the foreign firms' \\
\hline (Employment) & $\begin{array}{l}\text { employment in industry employment in } \mathrm{t}-1 \text {, at the industry } \\
\text { level. }\end{array}$ \\
\hline Spillover (Sale) & $\begin{array}{l}\text { Spillovers, measured by the share of the foreign firms' sales in } \\
\text { industry sales in } t-1 \text {, at the industry level. }\end{array}$ \\
\hline Spillover (Equity) & $\begin{array}{l}\text { Spillovers, measured by the share of the foreign firms' fixed } \\
\text { assets in the fixed assets of the industry in } t-1 \text {, at the industry } \\
\text { level. }\end{array}$ \\
\hline Investment $\mathrm{t}-1$ & $\begin{array}{l}\text { Investment in new technology measured by the expenditure on } \\
\text { new machinery and equipment per year, expressed in thousands } \\
\text { of kroons and lagged one year. This variable enters the equation } \\
\text { as the ratio of the investment to net sales of the firm. }\end{array}$ \\
\hline Human Capital & $\begin{array}{l}\text { The average labor cost of the firm, in kroons, constructed as the } \\
\text { ratio of the firm's wages to the number of employees. }\end{array}$ \\
\hline Labor Quality & $\begin{array}{l}\text { The share of skilled workers in the firm relative to its total } \\
\text { workforce. }\end{array}$ \\
\hline Intangible Assets & $\begin{array}{l}\text { Intangible assets, in thousands of kroons, relative net sales of } \\
\text { the firm. }\end{array}$ \\
\hline Export & $\begin{array}{l}\text { Total revenue from export, in thousands of kroons, relative to } \\
\text { net sales of the firm. }\end{array}$ \\
\hline $\begin{array}{l}\text { Herfindahl Index } \\
\text { (Foreign / Domestic) }\end{array}$ & $\begin{array}{l}\text { Herfindahl }=\sum_{i}\left(\frac{\text { Sale }_{i}}{\text { Sale }_{j}}\right)^{2} \\
\text { where } \mathrm{j} \text { indicates the industry and } \mathrm{i} \text { equals } \mathrm{f} \text { if the firm is } \\
\text { foreign and } \mathrm{d} \text { if the firm is domestic, at three-digit industry } \\
\text { classification. }\end{array}$ \\
\hline
\end{tabular}


Table A2: Mean and Standard Deviation of Main Variables for the Whole Sample (Domestic and Foreign Firms) 1994-1999.

\begin{tabular}{lrrr}
\hline Variables & Observation & Mean & $\begin{array}{r}\text { Standard } \\
\text { Deviation }\end{array}$ \\
\hline Net Sales & 2250 & 32830.8 & 78233.1 \\
Capital & 2250 & 10088.0 & 28897.9 \\
Materials & 2250 & 14422.4 & 42226.5 \\
Labor & 2248 & 133.9 & 248.5 \\
Human Capital & 2248 & 36.5 & 40.0 \\
Labor Quality & 1527 & 0.70 & 0.268 \\
Intangible Assets & 2011 & 626.29 & 3985.6 \\
Export & 2250 & 11274.1 & 36377.9 \\
Investment & 2249 & 2240.0 & 8559.3 \\
For. Herfindahl & 2250 & 0.062 & 0.135 \\
Dom Herfindahl & 2250 & 0.182 & 0.164 \\
\hline
\end{tabular}

Note: All variables are deflated using 1994 prices. 
Table 1: Foreign Presence by Industry

\begin{tabular}{l|cc|ccc|}
\hline \multirow{2}{*}{ Industry } & \multicolumn{3}{|c|}{ Number of Firms } & \multicolumn{3}{|c|}{ Foreign Presence in \% (spillover proxies) } \\
\cline { 2 - 6 } & $\begin{array}{c}\text { Domestic } \\
(1)\end{array}$ & $\begin{array}{c}\text { Foreign } \\
(2)\end{array}$ & $\begin{array}{c}\text { Employment } \\
(3)\end{array}$ & $\begin{array}{c}\text { Sales } \\
(4)\end{array}$ & $\begin{array}{c}\text { Equity } \\
(5)\end{array}$ \\
\cline { 2 - 6 } Manufacturing & 253 & 32 & 11.2 & 21.12 & 7.78 \\
food products & 111 & 35 & 16.3 & 16.41 & 14.64 \\
textile products & 26 & 15 & 46.9 & 67.49 & 29.56 \\
leather products & 108 & 18 & 6.7 & 9.73 & 14.13 \\
wood products & 107 & 22 & 22.8 & 29.73 & 14.49 \\
pulp \& paper & 8 & 0 & 0 & 0 & 0 \\
coke, petroleum products \& & & & & & \\
$\quad$ nuclear fuel & 38 & 25 & 15.9 & 21.75 & 35.43 \\
chemical products & 45 & 4 & 1.32 & 1.25 & 5.41 \\
rubber and plastic products & 65 & 45 & 52.5 & 78.84 & 35.96 \\
other non-metallic products & 92 & 21 & 11.9 & 20.33 & 13.43 \\
basic metal products & 100 & 20 & 8.8 & 15.78 & 9.4 \\
machinery \& equipment & 84 & 26 & 4.8 & 34.15 & 21.5 \\
electrical and optical & & & & & \\
equipment & 49 & 8 & 17.4 & 12.11 & 14.13 \\
transport equipment & 98 & 25 & 13.6 & 21.27 & 16.35 \\
furniture & 75 & 7 & 28.7 & 56.78 & 6.39 \\
Electricity, gas and water supply & 236 & 17 & 7.96 & 12.93 & 3.87 \\
Construction & 184 & 75 & 18.5 & 27.61 & 25.5 \\
Wholesale trade & 138 & 38 & 8.3 & 13.28 & 14.8 \\
Retail trade & 1817 & 433 & 15.27 & 24.45 & 15.16 \\
Total & &
\end{tabular}

Note: Equity share data are available only from 1995 to 1999. 
Table 2: The Net Impact of Spillovers to the Sales Growth of Domestic Firms.

\begin{tabular}{|c|c|c|c|}
\hline Variables & $(1)$ & (2) & (3) \\
\hline Spillover $(E m p l)_{t-1}$ & $\begin{array}{c}0.69 * \\
(27.13)\end{array}$ & - & - \\
\hline Spillover (Sales) ${ }_{\mathrm{t}-1}$ & & $\begin{array}{c}0.39 * \\
(19.52\end{array}$ & - \\
\hline Spillover (Equity) $\mathrm{t}-1$ & & - & $\begin{array}{c}0.17 * * \\
(2.02)\end{array}$ \\
\hline Intangible Assets & $\begin{array}{l}0.017 \\
(1.16)\end{array}$ & $\begin{array}{l}0.006 \\
(0.32)\end{array}$ & $\begin{array}{c}0.033^{* *} \\
(2.37)\end{array}$ \\
\hline (Investment) $\mathrm{t}-1$ & $\begin{array}{c}0.6^{*} \\
(11.94)\end{array}$ & $\begin{array}{l}0.38^{*} \\
(9.24)\end{array}$ & $\begin{array}{l}0.68^{*} \\
(9.31)\end{array}$ \\
\hline Human Capital & $\begin{array}{l}0.001^{*} \\
(4.24)\end{array}$ & $\begin{array}{c}0.001^{*} \\
(3.63)\end{array}$ & $\begin{array}{l}0.0005^{* *} \\
(2.52)\end{array}$ \\
\hline $\begin{array}{l}\text { Intangible Assets } \\
\text { x Spillover }\end{array}$ & $\begin{array}{c}-0.13 \\
(-0.78)\end{array}$ & $\begin{array}{l}0.005 \\
(0.05)\end{array}$ & $\begin{array}{c}-0.40^{* *} \\
(-2.0)\end{array}$ \\
\hline (Investment $)_{\mathrm{t}-1}$ & $-2.1 *$ & $-0.59 *$ & $-3.1^{*}$ \\
\hline x Spillover ${ }_{t-1}$ & $(-8.02)$ & $(-3.63)$ & $(-4.72)$ \\
\hline Human Capital & $-0.004 *$ & $-0.002 *$ & 0.0002 \\
\hline x Spillover ${ }_{t-1}$ & $(-3.98)$ & $(-3.57)$ & $(0.1)$ \\
\hline Export/Y & $\begin{array}{l}0.046^{*} \\
(6.62)\end{array}$ & $\begin{array}{l}0.055^{*} \\
(5.49)\end{array}$ & $\begin{array}{l}0.02^{* *} \\
(2.54)\end{array}$ \\
\hline For. Herfindahl & $\begin{array}{l}-0.28^{*} \\
(-21.1)\end{array}$ & $\begin{array}{c}-0.26^{*} \\
(-14.45)\end{array}$ & $\begin{array}{c}-0.2^{*} \\
(-7.39)\end{array}$ \\
\hline Dom. Herfindahl & $\begin{array}{l}-0.14^{*} \\
(-6.52)\end{array}$ & $\begin{array}{l}-0.16^{*} \\
(-5.82)\end{array}$ & $\begin{array}{l}-0.042 \\
(-1.41)\end{array}$ \\
\hline Inverse Mills Ratio & $\begin{array}{l}-1.56^{*} \\
(-27.06)\end{array}$ & $\begin{array}{l}-1.52^{*} \\
(-34.68)\end{array}$ & $\begin{array}{l}-1.12^{*} \\
(-20.52)\end{array}$ \\
\hline $\begin{array}{l}\text { Industry Dummies } \\
\text { Time Dummies }{ }^{\text {a }}\end{array}$ & $\begin{array}{l}\text { Yes } \\
\text { Yes }^{*}\end{array}$ & $\begin{array}{l}\text { Yes } \\
\text { Yes }\end{array}$ & $\begin{array}{l}\text { Yes } \\
\text { Yes }^{*}\end{array}$ \\
\hline $\begin{array}{l}\text { Nr. Observations } \\
\text { F-test }{ }^{\text {b }} \\
\text { P-value }\end{array}$ & $\begin{array}{c}1290 \\
113242 \\
(0.000)\end{array}$ & $\begin{array}{c}1290 \\
388541.4 \\
(0.000)\end{array}$ & $\begin{array}{c}1014 \\
1138708 \\
(0.000)\end{array}$ \\
\hline $\begin{array}{l}\text { Lagrangean Multiplier test of AR(1) for unbalanced panels } \\
\text { P-value }\end{array}$ & $\begin{array}{c}122.2 \\
(0.000)\end{array}$ & $\begin{array}{c}114.3 \\
(0.000)\end{array}$ & $\begin{array}{l}107.9 \\
(0.000)\end{array}$ \\
\hline $\begin{array}{l}\text { Wald-test for panel groupwise hetero-scedasticity } \\
\text { P-value }\end{array}$ & $\begin{array}{c}623 e+03 \\
(0.000)\end{array}$ & $\begin{array}{c}100 \mathrm{e}+03 \\
(0.000)\end{array}$ & $\begin{array}{l}647 e+03 \\
(0.000)\end{array}$ \\
\hline
\end{tabular}

Notes:

(i) Capital, labor and materials are included in these regressions along with a constant term. Their coefficients are all positive and significant at the $1 \%$ level.

(ii) The symbols *, ** and *** indicate $1 \%, 5 \%$ and $10 \%$ significance level, respectively.

(iii) The z-statistic is in parenthesis.

(iv) We tested for the exclusion of time dummies and, in all cases, we reject the hypothesis that time dummies are jointly equal to zero. Therefore, we mark time dummies with an asterisk. 
Table 3: The Impact of Firm Size and Trade Orientation on Spillovers to Domestic Firms.

\begin{tabular}{|c|c|c|c|c|c|}
\hline Variables & $\begin{array}{c}\text { Small } \\
\text { Firms } \\
(1)\end{array}$ & $\begin{array}{l}\text { Medium } \\
\text { Firms } \\
(2)\end{array}$ & $\begin{array}{l}\text { Large } \\
\text { Firms } \\
(3)\end{array}$ & $\begin{array}{c}\text { Exporting } \\
\text { Firms } \\
(4)\end{array}$ & $\begin{array}{c}\text { Non-Exporting } \\
\text { Firms } \\
(5)\end{array}$ \\
\hline Spillover $_{\mathrm{t}-1}$ (Empl.) & $\begin{array}{c}1.47^{*} \\
(14.04)\end{array}$ & $\begin{array}{l}0.56^{*} \\
(3.74)\end{array}$ & $\begin{array}{c}0.12 \\
(0.85)\end{array}$ & $\begin{array}{l}0.75^{*} \\
(7.56)\end{array}$ & $\begin{array}{c}0.82 * \\
(15.17)\end{array}$ \\
\hline Intangible Assets & $\begin{array}{l}0.043^{*} \\
(5.04)\end{array}$ & $\begin{array}{c}-0.11 \\
(-1.31)\end{array}$ & $\begin{array}{c}0.19 \\
(0.97)\end{array}$ & $\begin{array}{c}0.12 * * * \\
(1.74)\end{array}$ & $\begin{array}{l}0.023 \\
(1.29)\end{array}$ \\
\hline (Investment $)_{\mathrm{t}-1}$ & $\begin{array}{l}1.07^{*} \\
(7.08)\end{array}$ & $\begin{array}{l}0.92 * \\
(5.94)\end{array}$ & $\begin{array}{c}0.73^{*} \\
(10.72)\end{array}$ & $\begin{array}{c}0.71^{*} \\
(17.21)\end{array}$ & $\begin{array}{l}0.87^{*} \\
(4.58)\end{array}$ \\
\hline Human Capital & $\begin{array}{l}0.004^{*} \\
(8.39)\end{array}$ & $\begin{array}{l}-0.003 * \\
(-3.88)\end{array}$ & $\begin{array}{c}-0.0012^{* *} \\
(-2.03)\end{array}$ & $\begin{array}{c}0.0013^{*} \\
(5.00)\end{array}$ & $\begin{array}{l}0.003^{*} \\
(8.47)\end{array}$ \\
\hline $\begin{array}{l}\text { Intangible Assets } \\
\text { x Spillover }\end{array}$ & $\begin{array}{l}-0.44^{*} \\
(-5.93)\end{array}$ & $\begin{array}{c}-0.12 \\
(-0.07)\end{array}$ & $\begin{array}{c}-0.07 \\
(-0.07)\end{array}$ & $\begin{array}{c}-0.67 * * * \\
(-1.86)\end{array}$ & $\begin{array}{c}-0.19 \\
(-0.92)\end{array}$ \\
\hline $\begin{array}{l}\text { (Investment })_{\mathrm{t}-1} \\
\text { x Spillover }\end{array}$ & $\begin{array}{l}-2.7^{* *} \\
(-1.96)\end{array}$ & $\begin{array}{c}-2.9 * \\
(-5.07)\end{array}$ & $\begin{array}{l}-2.26^{*} \\
(-3.62)\end{array}$ & $\begin{array}{c}-2.5^{*} \\
(-9.31)\end{array}$ & $\begin{array}{c}-2.02 * * * \\
(-1.94)\end{array}$ \\
\hline $\begin{array}{l}\text { Human Capital } \\
\text { x Spillover }\end{array}$ & $\begin{array}{l}-0.03^{*} \\
(-12.09)\end{array}$ & $\begin{array}{l}-0.004 \\
(-0.91)\end{array}$ & $\begin{array}{l}0.007^{*} \\
(2.72)\end{array}$ & $\begin{array}{c}-0.004 * * * \\
(-1.87)\end{array}$ & $\begin{array}{l}-0.013^{*} \\
(-5.66)\end{array}$ \\
\hline Export/Y & $\begin{array}{l}0.09 * \\
(3.61)\end{array}$ & $\begin{array}{l}0.0013 \\
(0.06)\end{array}$ & $\begin{array}{l}-0.002 \\
(-0.17)\end{array}$ & (- & (- \\
\hline For. Herfindahl & $\begin{array}{l}-0.37^{*} \\
(-6.52)\end{array}$ & $\begin{array}{l}0.10^{*} \\
(2.59)\end{array}$ & $\begin{array}{l}-0.31^{*} \\
(-4.96)\end{array}$ & $\begin{array}{c}-0.38^{*} \\
(-14.19)\end{array}$ & $\begin{array}{l}-0.25^{*} \\
(-7.76)\end{array}$ \\
\hline Dom. Herfindahl & $\begin{array}{l}-0.23^{*} \\
(-4.91)\end{array}$ & $\begin{array}{l}-0.18^{*} \\
(-4.46)\end{array}$ & $\begin{array}{l}-0.33^{*} \\
(-6.73)\end{array}$ & $\begin{array}{l}-0.28^{*} \\
(-8.15)\end{array}$ & $\begin{array}{l}-0.071 \\
(-1.18)\end{array}$ \\
\hline Inverse Mills Ratio & $\begin{array}{c}-2.9 * \\
(-10.96)\end{array}$ & $\begin{array}{l}-4.06^{*} \\
(-8.59)\end{array}$ & $\begin{array}{c}-1.9^{*} \\
(-13.68)\end{array}$ & $\begin{array}{l}-1.49 * \\
(-19.05)\end{array}$ & $\begin{array}{l}-1.24^{*} \\
(-17.42)\end{array}$ \\
\hline $\begin{array}{l}\text { Industry Dummies } \\
\text { Time Dummies }\end{array}$ & $\begin{array}{l}\text { Yes } \\
\text { Yes }^{*}\end{array}$ & $\begin{array}{l}\text { Yes } \\
\text { Yes }^{*}\end{array}$ & $\begin{array}{l}\text { Yes } \\
\text { Yes }^{*}\end{array}$ & $\begin{array}{l}\text { Yes } \\
\text { Yes }^{*}\end{array}$ & $\begin{array}{l}\text { Yes } \\
\text { Yes }^{*}\end{array}$ \\
\hline Nr. Observations & 528 & 233 & 427 & 727 & 487 \\
\hline $\begin{array}{l}\text { Wald-test for joint } \\
\text { significance of } \\
\text { coefficients } \\
\text { P-value }\end{array}$ & 54635.7 & 14896.6 & 185129.3 & $3.95 E+07$ & 800606.3 \\
\hline
\end{tabular}

Notes:

(i) Capital, labor and materials are included in these regressions along with a constant term. Their coefficients are all positive and significant at the $1 \%$ level.

(ii) The symbols *, $* *$ and $* * *$ indicate $1 \%, 5 \%$ and $10 \%$ significance level, respectively.

(iii) The z-statistic is in parenthesis.

(iv) We tested for the exclusion of time dummies and, in all cases, we reject the hypothesis that time dummies are jointly equal to zero. Therefore, we mark time dummies with an asterisk. 
Table 4: Spillovers to State-Owned and Private Firms.

\begin{tabular}{|c|c|c|c|}
\hline Variables & $\begin{array}{l}\text { State-owned } \\
\text { Firms } \\
\text { (1) }\end{array}$ & $\begin{array}{l}\text { Outsider-owned } \\
\text { Firms } \\
\text { (2) }\end{array}$ & $\begin{array}{l}\text { Insider-owned } \\
\text { Firms } \\
\text { (3) }\end{array}$ \\
\hline Spillover $_{\mathrm{t}-1}$ (Empl.) & $\begin{array}{l}0.25 * \\
(2.64)\end{array}$ & $\begin{array}{l}0.84^{*} \\
(8.26)\end{array}$ & $\begin{array}{c}0.35^{* *} \\
(2.43)\end{array}$ \\
\hline Intangible Assets & $\begin{array}{l}-0.72^{*} \\
(-32.4)\end{array}$ & $\begin{array}{l}-0.41^{*} \\
(-3.21)\end{array}$ & $\begin{array}{l}1.9^{*} \\
(4.49)\end{array}$ \\
\hline$(\text { Investment })_{\mathrm{t}-1}$ & $\begin{array}{l}0.66^{*} \\
(7.59)\end{array}$ & $\begin{array}{l}0.83^{*} \\
(6.94)\end{array}$ & $\begin{array}{l}-0.005 \\
(-0.02)\end{array}$ \\
\hline Human Capital & $\begin{array}{c}-0.0002 \\
(-0.45)\end{array}$ & $\begin{array}{l}0.004^{*} \\
(8.77)\end{array}$ & $\begin{array}{c}0.002^{* *} \\
(2.36)\end{array}$ \\
\hline $\begin{array}{l}\text { Intangible Assets } \\
\text { x Spillover }\end{array}$ & $\begin{array}{l}9.01^{*} \\
(32.67)\end{array}$ & $\begin{array}{l}2.68^{*} \\
(4.05)\end{array}$ & $\begin{array}{c}-2.6^{*} \\
(-2.98)\end{array}$ \\
\hline $\begin{array}{l}\text { (Investment) })_{\mathrm{t}-1} \\
\quad \mathrm{x} \text { Spillover }\end{array}$ & $\begin{array}{c}-0.43 \\
(-0.63)\end{array}$ & $\begin{array}{l}-3.46^{*} \\
(-8.47)\end{array}$ & $\begin{array}{c}1.7 \\
(1.6)\end{array}$ \\
\hline $\begin{array}{l}\text { Human Capital } \\
\text { x Spillover } \\
\text { t-1 }\end{array}$ & $\begin{array}{l}-0.001 \\
(-0.44)\end{array}$ & $\begin{array}{l}-0.002 \\
(-0.84)\end{array}$ & $\begin{array}{l}-0.004 \\
(-1.36)\end{array}$ \\
\hline Export/Y & $\begin{array}{l}-0.008 \\
(-0.98)\end{array}$ & $\begin{array}{l}0.14^{*} \\
(8.46)\end{array}$ & $\begin{array}{l}-0.011 \\
(-0.43)\end{array}$ \\
\hline For. Herfindahl & $\begin{array}{c}-0.60^{*} \\
(-22.75)\end{array}$ & $\begin{array}{l}-0.17 * * \\
(-2.34)\end{array}$ & $\begin{array}{c}-0.30^{* *} \\
(-2.36)\end{array}$ \\
\hline Dom. Herfindahl & $\begin{array}{l}-0.35^{*} \\
(-6.49)\end{array}$ & $\begin{array}{l}-0.28^{*} \\
(-3.75)\end{array}$ & $\begin{array}{l}-0.08 \\
(-1.6)\end{array}$ \\
\hline Inverse Mills Ratio & $\begin{array}{l}-1.81^{*} \\
(-24.81)\end{array}$ & $\begin{array}{c}-1.8^{*} \\
(-11.16)\end{array}$ & $\begin{array}{l}-1.24^{*} \\
(-7.76)\end{array}$ \\
\hline $\begin{array}{l}\text { Industry Dummy } \\
\text { Time Dummy }\end{array}$ & $\begin{array}{l}\text { Yes } \\
\text { Yes }^{*}\end{array}$ & $\begin{array}{l}\text { Yes } \\
\text { Yes }^{*}\end{array}$ & $\begin{array}{l}\text { Yes } \\
\text { Yes }^{*}\end{array}$ \\
\hline Nr. Observations & 455 & 374 & 334 \\
\hline $\begin{array}{l}\text { Wald-test for joint significance of } \\
\text { coefficients }\end{array}$ & 249393.8 & 19722.2 & 13473 \\
\hline P-value & $(0.000)$ & $(0.000)$ & $(0.000)$ \\
\hline
\end{tabular}

Notes:

(i) Capital, labor and materials are included in these regressions along with a constant term. Their coefficients are all positive and significant at the $1 \%$ level.

(ii) The symbols *,** and $* * *$ indicate $1 \%, 5 \%$ and $10 \%$ significance level, respectively.

(iii) The z-statistic is in parenthesis.

(iv) We tested for the exclusion of time dummies and, in all cases, we reject the hypothesis that time dummies are jointly equal to zero. Therefore, we mark time dummies with an asterisk. 


\section{REFERENCES}

Acs, Zoltan J., Audretsch, David B., 1990. Innovation and Small Firms. The MIT Press Cambridge, Massachusetts London, England.

Acs, Zoltan J., Audretsch, David B., Feldman, Maryann B., 1994. R\&D spillovers and recipient firm size. Review of Economics and Statistics 76 (2), 336-340.

Acs, Zoltan J., Carlsson, Bo, Karlsson, Charlie, 1999. Entrepreneurship, Small and Medium-sized Enterprises and the Macroeconomy. Cambridge University Press, Cambridge.

Aitken, Brian J., Harrison, Ann E., 1999. Do domestic firms benefit from direct foreign investment? Evidence from Venezuela. American Economic Review 89 (3), 605618.

Aitken, Brian J., Harrison, Ann E., Lipsey, Robert E., 1997. Wages and foreign ownership: A comparative study of Mexico, Venezuela and the United States. Journal of International Economics 43 (1), 103-132.

Blanchard, Olivier J., Aghion, Philippe, 1996. On insider privatization. European Economic Review 40 (3-5), 759-766.

Blomström, Magnus, Wolff, Edward N., 1994. Multinational corporations and productivity convergence in Mexico. In: Blomström, Magnus, Wolff, Edward N., Convergence of Productivity: Cross-national Studies and Historical Evidence, Oxford and New York: Oxford University Press, pp. 243-259.

Blomström, Magnus, Kokko, Ari, 1996. Multinational corporations and spillovers. Journal of Economic Surveys 12(2), 1-31. 
Blomström, Magnus, Persson, Håkan, 1983. Foreign investment and spillover efficiency in an underdeveloped economy: Evidence from the Mexican manufacturing industry. World Development 11 (6), 493-501.

Blomstrom, Magnus, Zejan, Mario, Kokko, Ari, 2000. Foreign Direct Investment: Firm and Host Country Strategies. Macmillan Press, London.

Borensztein, Eduardo, De Gregorio, Jose, Lee, Jong-Wha, 1998. How does foreign direct investment affect economic growth? Journal of International Economics 45 (1), 115-135.

Buck, Trevor, Filatochev, Igor, Wright Mike, Zhukov, Vladimir, 1998. Corporate governance and employee ownership in an economic crisis: Enterprise strategies in the former USSR. Journal of Comparative Economics 27 (3), 459-474.

Buckley, Peter J., Clegg, Jeremy, Wang, Chengqi, 2002. The impact of inward FDI on the performance of Chinese manufacturing firms. Journal of International Business Studies 33 (4), 637-655.

Caves, Richard E., 1974. Multinational firms, competition and productivity in host country markets. Economica 41 (162), 176-193.

Caves, Richard E., 1999. Multinational Enterprise and Economic Analysis. 2nd edition, Cambridge University Press, Cambridge.

Christofides, Louise N., Oswald, Andrew J., 1992. Real wage determination and rentsharing in collective bargaining agreements. Quarterly Journal of Economics 107 (3), 985-1002. 
Chung, Wilbur C., Mitchell, Will, Yeung, Bernard, 2003. Foreign direct investment and host country productivity: The American automotive component industry in the 1980s. Journal of International Business Studies 34 (2), 199-219.

Chuang, Yih-Chyi, Lin, Chi-Mei, 1999. FDI, R\&D and spillover efficiency: Evidence from Taiwan’s manufacturing firms. Journal of Development Studies 35 (4), 117137.

Cohen, Wesley M., Levinthal, Daniel A., 1989. Innovation and learning: The two faces of R\&D. Economic Journal 99 (397), 569-596.

Coricelli, Fabrizio, Djankov, Simeon, 2001. Hardened budgets and enterprise restructuring: Theory and application to Romania. Journal of Comparative Economics 29 (4), 749-763.

Djankov, Simeon, Hoekman, Bernard, 2000. Foreign investment and productivity growth in Czech Enterprises. World Bank Economic Review 14 (1), 49-64.

Djankov, Simeon, Murrell, Peter, 2002. Enterprise restructuring in transition: A quantitative survey. Journal of Economic Literature 40 (3), 739-792.

Dunning, John, 1992. Multinational Enterprises and the Global Economy. AddisonWesley, Harlow.

Statistical Office of Estonia, 2000. Enterprises in Estonia. Ministry of Economy, Statistical Office of Estonia.

Estrin, Saul, 2002. Competition and corporate governance in transition. Journal of Economic Perspectives 16 (1), 101-124.

Estrin, Saul, Wright, Mike, 1999. Corporate governance in the former Soviet Union: An overview. Journal of Comparative Economics 27 (3), 398-421. 
Feinberg, Susan E., Majumdar, Sumit K., 2001. Technology spillovers from foreign direct investment in the Indian pharmaceutical industry. Journal of International Business Studies 32 (3), 421-437.

Felipe, Jesus, 1999. Total factor productivity growth in East Asia: A critical survey. Journal of Development Studies 35 (4), 1-41.

Fosuri, Andrea, Motta, Massimo, Rønde, Thomas, 2001. Foreign direct investment and spillovers through workers’ mobility. Journal of International Economics 53 (1), 205-222.

Frydman, Roman, Phelps, Edmund S., Rapaczynski, Andrzej, Shleifer, Andrei, 1993. Needed mechanisms of corporate governance and finance in Eastern Europe. Economics of Transition 1 (2), 171-207.

Frydman, Roman, Gray, Cheryl, Hessel, Marek, Rapaczynski, Andrzej, 1999. When does privatization work? The impact of private ownership on corporate performance in the transition economies. The Quarterly Journal of Economics 111 (4), 11531191.

Gershenberg, Irving, 1987. The training and spread of managerial know-how. A comparative analysis of multinationals and other firms in Kenya. World Development 15 (7), 931-939.

Glass, Amy J., Saggi, Kamal, 2002. Multinational firms and technology transfer. Scandinavian Journal of Economics 104 (4), 495-513..

Globerman, Steven, 1979. Foreign direct investment and "spillover" efficiency benefits in Canadian manufacturing industries. Canadian Journal of Economics 12 (1), 4256. 
Görg, Holger, Strobl, Erik, 2001. Multinational companies and productivity spillovers: A meta-analysis with a test for publication bias. Economic Journal 111 (475), 723739.

Greene, William H., 2003. Econometric Analysis. Pearson Education, Inc., Upper Saddle River, New Jersy.

Griffith, Rachel, 1999. Using the ADR establishment level data to look at the foreign ownership and productivity in the United Kingdom. Economic Journal 109 (456), 416-441.

Haddad, Mona, Harrison, Ann E., 1993. Are there positive spillovers from direct foreign investment? Evidence from panel data for Morocco. Journal of Development Economics 42 (1), 51-74.

Haskel, Jonathan E., Pereira, Sonia C., Slaughter, Matthew J., 2002. Does inward FDI boost the productivity of domestic firms? Working Paper, No. 8724. NBER, London.

Harris, Richard, Robinson, Catherine, 2003. Foreign ownership and productivity in the United Kingdom estimates for UK manufacturing using the ARD. Review of Industrial Organization 22 (3), 207-223.

IMF, World Bank, OECD and EBRD, 1991. A Study of the Soviet Economy. OECD, Paris.

Jones, Derek C., Klinedienst, Mark, Rock, Charles, 1998. Productive efficiency during transition: Evidence from Bulgarian panel data. Journal of Comparative Economics 26 (3), 446-464. 
Jones, Derek C., Mygind, Niels, 1999. The nature and determinants of ownership changes after privatization: Evidence from Estonia. Journal of Comparative Economics 27 (3), 422-441.

Kamien, Morton I., Zang, Israel, 2000. Meet me halfway: Research joint ventures and absorptive capacity. International Journal of Industrial Organization 18 (7), 9951012.

Kathuria, Vinish, 2000. Productivity spillovers from technology transfer to Indian manufacturing firms. Journal of International Development 12 (3), 334-369.

Keller, Wolfgang, 1996. Absorptive capacity: On the creation and acquisition of technology in development. Journal of Development Economics 49 (1), 199-227.

Kinoshita, Yuko, 2001. R\&D and technology spillovers via FDI: Innovation and absorptive capacity. Discussion Paper No. 2775. CEPR, London.

Kogut, Bruce, Zander, Udo, 1993. Knowledge of the firm and the evolutionary theory of multinational corporation. Journal of International Business Studies 24 (3), 625646.

Konings, Jozef, 2001. The effects of foreign direct investment on domestic firms: Evidence from firm-level panel data in emerging economies. Economics of Transition 9 (3), 619-633.

Kokko, Ari, 1994. Technology, market characteristics, and spillovers. Journal of Development Economics 43 (2), 279-293.

Kokko, Ari, Tasini, Ruben, Zejan, Mario, 1996. Local technological capability and productivity spillovers from FDI in the Uruguayan manufacturing sector. Journal of Development Studies 32 (4), 602-611. 
Lall, Sanjaya, 1978. Transnationals, domestic enterprises and industrial structure in LDSs: A Survey. Oxford Economic Papers 30 (2), 217-248.

Lane, Peter J., Lubatkin, Michael, 1998. Relative absorptive capacity and interorganizational learning. Strategic Management Journal 19 (5), 461-477.

Liu, Xiaming, Siler, Pamela, Wang, Chengqi, Wei, Yingqi, 2000. Productivity spillovers from foreign direct investment: Evidence from UK industry level panel data. Journal of International Business Studies 31 (3), 407-425.

Liu, Zhiqiang, 2002. FDI and technology spillover: Evidence from China. Journal of Comparative Economics 30, 3:579-602.

Lyles, Marjorie, Salk, Jane S., 1996. Knowledge acquisition from foreign parents in international joint ventures: An empirical examination in the Hungarian context. Journal of International Business Studies 27 (5), 877-903.

Mansfield, Edwin, Romeo, Anthony, 1980. Technology transfer to overseas subsidiaries by U.S based firms. Quarterly Journal of Economics 95 (4), 737-750.

Meyer, Klaus E., 2001. International business research in transition economies. In: Brewer, Thomas L., Rugman, Alan M. (Eds.), Oxford Handbook of International Business, Oxford University Press, Oxford, pp. 716-759.

Prasnikar, Janez, Svejnar, Jan, 1998. Investment and wages during transition: Evidence from Slovene firms. Working Paper No. 184. William Davidson Institute, Michigan.

Schaffer, Mark E., 1998. Do firms in transition economies have soft budget constraints? A reconsideration of concepts and evidence. Journal of Comparative Economics 26 (3), 80-103. 
Schumpeter, Joseph A., 1950. Capitalizm, Socializm and Democracy. 3rd edition, New York, NY: Harper and Row.

Sjöholm, Fredrik, 1999. Technology gap, competition and spillovers from direct foreign investment: Evidence from establishment data. Journal of Development Studies 36 (1), 53-73.

United Nations, 2001. World Investment Report 2001. United Nations, Geneva.

Wang, Jian-Ye, Blomström, Magnus, 1992. Foreign investment and technology transfer: A simple model. European Economic Review 36 (1), 137-155.

Yudaeva, Ksenia, Kozlov, Kostantin, Melentieva, Natalia, Ponomareva, Natalia, 2003. Does foreign ownership Matter? Russian experience. Economics of Transition 11(3), 383-410.

Zukowska-Gagelmann, Katarzyna, 2000. Productivity spillovers from foreign direct investment in Poland. Economic Systems 24 (3), 223-256.

\section{${ }^{1}$ Acknowledgements:}

We thank Niels Mygind for permission to use his Estonian enterprise dataset. For very helpful comments, we thank Jozef Konings, Tina Pedersen, the editor John Bonin and three anonymous reviewers. Earlier versions have been presented at LICOS, Catholic University of Leuven, the Druid Academy Winter Conference, the Spring Meeting of Young Economists, Paris, and the EACES conference in Forli, Italy.

${ }^{2}$ Empirical evidence on spillovers from labor mobility is ambiguous. Since MNCs typically pay higher wages to prevent loosing trained staff, low labor mobility from foreign to domestic firms, especially in developing countries, is expected. For example, 
Gershenberg (1987) finds only 16\% of labor movement from MNCs to Kenyan firms. In a study of Venezuela, Mexico and the U.S., Aitken, Harrison and Lipsey (1995), show that higher levels of FDI are associated with higher wages in all three countries. However, in the two developing countries, the authors find no evidence of domestic firms also raising wages.

${ }^{3}$ Wang and Blomstrom (1992) highlight the importance of the learning efforts, i.e., absorptive capacity of a local firm in increasing the rate of technology transfer. Using a game theoretic framework, Kamien and Zang (2000) show that a firm should meet the foreign firm halfway and invest in R\&D so that it is able to absorb the advanced technology.

${ }^{4}$ In a country-level study, Borensztein et al. (1998) include an interaction term of human capital with FDI and find that FDI contributes to higher productivity growth only if the country possesses a minimum threshold of human capital.

${ }^{5}$ Fixed Effects (FE) estimations, which establish the robustness of our results, are available to interested readers from the authors upon request.

${ }^{6}$ This definition is used by the OECD. Other researchers, e.g., Sjöholm (1999), take 15\% of equity owned by foreigners as the threshold. Haddad and Harrison (1993) consider firms with at least $5 \%$ equity owned by foreigners to be foreign firms, whereas Djankov and Hoekman (1998) consider the relevant threshold to be 20\%. We considered changing the threshold from $10 \%$ to $20 \%$, but only 10 observations would need to be reclassified. So we consider the results with $10 \%$ to be sufficiently robust.

${ }^{7}$ Table 2 presents the results of a first order autocorrelation and heteroskedasticity test, exploiting the panel nature of the data. The null hypothesis of no autocorrelation and no 
heteroskedasticity is rejected at any significance level. We correct for both simultaneously by employing a GLS regression for panel data that corrects for a general form of heteroskedasticity and group specific first order autocorrelation structure.

${ }^{8}$ To check the robustness of our results, we re-run the main regressions in Table 2 using the share of skilled labor to total workforce instead of the measure of human capital and market share instead of the Herfindahl indexes. We do not use the share of skilled labor to total workforce as a proxy for the quality of human capital because, in $65 \%$ of cases, the share of skilled labor force is greater than 0.7 , which suggests that there might be biases in classifying employees into skilled versus unskilled categories. Nevertheless, we find that the spillover variable has the same sign and significance when spillover is measured as a share in sales and employment. In all cases, the coefficient of labor quality is positive and usually significant, whereas its interaction with the spillover variable is negative and significant. Furthermore, we re-run all regressions using lagged market share instead of Herfindahl indexes. In all cases, except when spillover is measured as a share in equity, the spillover variable is positive and significant. In addition, the coefficient of market share is positive and significant.

${ }^{9}$ In most industries the TFP growth difference between foreign and domestic firms is positive, suggesting that domestic firms do not catch up with foreign firms.

${ }^{10}$ Small firms are those with a maximum of 50 employees, medium-sized firms are those with between 50 and 100 employees, while large firms are those with more than 100 employees. To investigate why large firms do not benefit from a foreign presence, we examined the differences in means of investment in intangible assets per unit of sales, investment in new machinery per unit of capital, capital intensity, long-term bank debt 
and long-term trade credit per unit of capital for large firms versus small and medium firms. The test reveals that large firms do not display significantly different behavior from that of small and medium sized firms. This result does not support the Schumpeterian view that large firms benefit more from foreign presence. Furthermore, large firms borrow from banks significantly more than do small and medium sized firms and they also have significantly higher long-term trade credits per unit of capital. These facts suggest that large firms may have soft budget constraints (Schaffer, 1998; Coricelli and Djankov, 1999).

${ }^{11}$ Increased foreign firm concentration appears to enhance sales growth for medium-size domestic firms. However, in several industries such as textile products, rubber and plastic products, basic metal products, furniture, and wholesale trade, domestic firms have higher TFP growth than foreign firms on average, which suggest that domestic firms are catching up. These industries are labor intensive and typically export-oriented in countries like Estonia, which may explain the low market share of foreign firms. In addition, medium-size firms have the highest market share among domestic firms in these industries. Therefore, the more efficient domestic medium-size firms are likely to focus on maintaining their dominant position. We have Re-run the regression for medium-size firms excluding these industries, and found a negative sign and insignificant coefficient of the concentration of foreign firms.

${ }^{12}$ We confirm this significance of the difference between this coefficient and the other two by an F-Test. 